\title{
Comparative Economics of Wheat Cultivation Establishment Techniques in Haryana
}

\author{
Ajay Singh ${ }^{1}$, Dalip Kumar Bishnoi ${ }^{2}$, Raj Kumar ${ }^{3^{*}}$ and Sumit ${ }^{4}$
}

${ }^{1}$ Research Scholar, Department of Agricultural Economics CCS HAU, Hisar, Haryana, India

${ }^{2}$ Assistant Scientist, Department of Agricultural Economics CCS HAU, Hisar, Haryana, India

${ }^{3}$ Senior Research Fellow, Directorate of Human Resource Management, CCS HAU, Hisar, Haryana, India

${ }^{4}$ Assistant Professor, Department of Agricultural Economics CCS HAU, Hisar, Haryana, India

*Corresponding author: rajkumarkashyap301@gmail.com (ORCID ID: 0000-0003-3089-6234)

Received: $11-01-2021$

Revised: $14-02-2021$

Accepted: 03-03-2021

\begin{abstract}
The study was conducted in Karnal and Kaithal districts of Haryana during the year 2017-18. The results of the revealed that the share of variable cost as well as fixed cost in total cost of conventional technique of wheat were estimated to be was higher than the conservation techniques (ZTT and THST). The highest cost was incurred on fertilizer investment in variable cost. On the other side in case of fixed cost, highest share were incurred on rental value of land in conventional as well as conservation techniques of wheat in both the districts. The highest gross as well as net returns were found to be higher in turbo happy seeder technique (THST) over zero tillage technique and conventional technique in Karnal and Kaithal district of Haryana. As far as benefit cost analysis, turbo happy seeder technique was recorded profitable over zero tillage technique and conventional technique in the study area.
\end{abstract}

\section{Highlights}

(0 Benefit cost analysis, turbo happy seeder technique was recorded profitable over zero tillage technique and conventional technique in the study area.

Keywords: Conventional Technique, Zero Tillage Technique, Turbo Happy Seeder Technique

Wheat (Triticum aestivum L.) is a crop of universal importance. In World, total area under wheat cultivation was 219 million hectares and production 771.7 million tonnes in 2018 with a productivity of $3531 \mathrm{~kg} / \mathrm{ha}$. India ranks second position in wheat production all over the world with area 30.60 million hectares and production 98.51 million tonnes in year 2018 with a productivity of $3219 \mathrm{~kg} / \mathrm{ha}$. Main wheat producing states in India are Uttar Pradesh, Madhya Pradesh, Punjab, Haryana and Rajasthan.

Haryana is important wheat producing state in the country with area and production 2.55 million hectares and 12.57 million tonnes in 2018, respectively. The productivity of wheat in Haryana state was $4925 \mathrm{~kg} / \mathrm{ha}$ in the year 2018. The major challenges to wheat production and productivity in
Haryana are to increase its profitability. Savings in input cost, fuel consumption and irrigation water use have been reported due to implementation of zero tillage in wheat cultivation (Malik et al. 2003). The new challenges demand economical use of resource and conservation to satisfy the rising needs. Troubles with conservation have assumed importance in view of widespread resource degradation problems and the need to reduce production cost, increase profitability and make agriculture more competitive. To attain the target of sustainable agriculture, scientists are now more

How to cite this article: Singh, A., Bishnoi, D.K., Kumar, R. and Sumit. (2021). Comparative Economics of Wheat Cultivation Establishment Techniques in Haryana. Economic Affairs, 66(1): 93-99.

Source of Support: None; Conflict of Interest: None (c) $\stackrel{9}{5}$ 
serious than ever before. Conservation Agriculture (CA) has been recognized as the immediate as well as long-term solution to achieve goals of sustaining productivity, economic natural resource based and growth of the Indian farmers. The term CA refers to the system of raising crops without tilling the soil while retaining crop residues on the soil surface. The key elements which characterize CA includes minimum soil disturbance by adopting no-tillage and least amount traffic for agricultural operations, leaving and managing the crop residues on the soil surface, and adopting spatial and temporal crop sequencing/crop rotations to derive maximum benefits from inputs and minimize adverse environmental impacts (Abrol and Sangar 2006). CA aims to attain sustainable and profitable agriculture and consequently aims at improved livelihoods of farmers through the application of the CA principles and it has been proven to work in a variety of agro environmental zones and farming systems.

Even as some farmers may achieve maximum physical yield per unit of land at a high cost, some others achieve maximum profit per unit of inputs used. As well in the process of maintaining maximum yield and returns, a number of farmers may ignore the environmentally undesirable consequences, if any, of their resource use amount. Burning of rice stubbles is extensively practised in Punjab, India, due to the lack of proper machinery to direct tillage wheat into combine-harvested rice residues. While burning is a speedy and cheap option, and allows fast turnaround between crops, it has severe effects on human and animal health due to air pollution, reduced soil fertility due to loss of nutrients and organic matter, and green house gas (GHG) emissions. The newly developed Turbo Happy Seeder (THS) solves the technical trouble associated with direct tillage into rice residues. The key aim of the present study was to conducted introductory valuation of the direct economic benefits and costs to farmers regarding use of the HS in comparison with the recent practices of straw burning followed by direct tillage or conventional tillage prior to sowing.

\section{MATERIALS AND METHODS}

The study was carried out in Karnal and Kaithal districts of Haryana state. Karnal and Kaithal district of Haryana were selected purposively on the basis of highest area under conservation techniques (ZTT and THST) of wheat cultivation. Further forty respondents were interviewed for each techniques namely conventional technique (CT), zero tillage technique (ZTT) and turbo happy seeder technique (THST). Thus a total of 120 sample farmers were interviewed for the study. Both primary as well as secondary data, related to economics of the various establishment techniques of wheat cultivation, were collected during the agricultural year 2017-18. Simple average tabulation techniques were used to work out economics of the planting methods of the paddy cultivation in the study area.

\section{RESULTS AND DISCUSSION}

\section{Cost of cultivation in conventional technique (CT), zero tillage technique (ZTT) and turbo happy seeder technique (THST)}

Cost of wheat cultivation under conventional technique $(\mathrm{CT})$, zero tillage technique (ZTT) and turbo happy seeder technique (THST) in wheat in Karnal district of Haryana is presented in Table 1. Per hectare total cost of cultivation in conventional technique of wheat ( $₹ 100945.12$ ) was estimated to be higher as compared to zero tillage and turbo happy seeder technique i.e. ( $₹$ 94370.74) and ( $₹$ 91682.99) respectively. The share of variable cost as well as fixed cost in total cost of conventional technique of wheat was observed 36.31 per cent ( $₹$ 36650.36/ha) and 63.69 per cent ( $₹$ 64294.76/ha) respectively. In case of zero tillage technique of wheat the share of variable cost as well as fixed cost were found to be 33.15 per cent ( $₹ 31362.70 / \mathrm{ha}$ ) and 66.85 per cent (₹ 63008.04/ha). Similarly in case of turbo happy seeder technique of wheat the share of variable cost as well as fixed cost were found to be 31.15 per cent (₹ $28566.83 /$ ha) and 68.85 per cent ( $₹ 63116.16 /$ ha) respectively in the study area. Similar results were obtained by Grover et al. (2011) in their study on comparative analysis of traditional /conventional planting system with zero tillage farms in Haryana. Profitability from wheat cultivation in Karnal district of Haryana is presented in Table 2. Per hectare gross returns (₹ 110367) as well as net returns (₹ 18684.01)were estimated to be higher in turbo happy seeder technique (THST) as compared 
Table 1: Cost of wheat cultivation in Karnal district of Haryana (₹/ha.)

\begin{tabular}{|c|c|c|c|c|c|c|c|}
\hline \multirow{2}{*}{ Sl. No. } & \multirow{2}{*}{ Inputs } & \multicolumn{2}{|r|}{ CT } & \multicolumn{2}{|r|}{ ZTT } & \multicolumn{2}{|c|}{ THST } \\
\hline & & No./Qty & Value (₹) & No./Qty & Value (₹) & No./Qty & Value (₹) \\
\hline 1 & Preparatory Tillage & 4.20 & $5187(5.14)$ & & & & \\
\hline 2 & Pre-sowing Irrigation & & $785.4(0.78)$ & & $763.23(0.81)$ & & \\
\hline 3 & Seed $(\mathrm{kg})$ & 121.03 & $2783.69(2.76)$ & 107.69 & $2476.92(2.63)$ & 104.60 & $2405.90(2.62)$ \\
\hline 4 & Seed Treatment & & $146.97(0.15)$ & & $163.02(0.17)$ & & $164.26(0.18)$ \\
\hline 5 & Sowing & & $1071.98(1.06)$ & & $1883.38(2)$ & & $3112.20(3.39)$ \\
\hline 6 & Ridging & & $244.53(0.24)$ & & & & \\
\hline 7 & FYM (qtls) & 75.04 & $2551.41(2.23)$ & 69.43 & $2082.83(2.21)$ & & \\
\hline \multirow[t]{6}{*}{8} & Fertilizer Nutrients & & & & & & \\
\hline & Urea $(\mathrm{Kg})$ & 287.14 & $1694.12(1.68)$ & 290.23 & $1712.33(1.82)$ & 290.23 & $1712.33(1.87)$ \\
\hline & $\mathrm{DAP}(\mathrm{Kg})$ & 135.60 & $3254.47(3.22)$ & 136.10 & $3266.33(3.47)$ & 135.60 & $3254.47(3.55)$ \\
\hline & Potash $(\mathrm{Kg})$ & 14.82 & $177.84(0.18)$ & & & & \\
\hline & Zinc Sulphate (Kg) & 5.56 & $166.73(0.17)$ & 8.65 & $259.35(0.28)$ & 13.39 & $407.55(0.44)$ \\
\hline & \multicolumn{2}{|l|}{ Total Fertilizer Investment } & $5293.16(5.24)$ & & $5238.01(5.56)$ & & $5374.35(5.86)$ \\
\hline 9 & \multicolumn{2}{|l|}{ Fertilizer Application cost } & $532.29(0.53)$ & & $502.65(0.53)$ & & $556.99(0.61)$ \\
\hline 10 & Irrigation & 4.75 & $3727.23(3.69)$ & 5 & $3816.15(4.05)$ & 4 & $2912.13(3.18)$ \\
\hline \multirow[t]{2}{*}{11} & \multicolumn{7}{|l|}{ Hoeing/ Weeding } \\
\hline & Chemical & & $1483.24(1.47)$ & & $1420.25(1.51)$ & & $1359.74(1.48)$ \\
\hline 12 & $\begin{array}{l}\text { Weedicides application } \\
\text { cost }\end{array}$ & & $864.50(0.86)$ & & $827.45(0.88)$ & & $792.87(0.86)$ \\
\hline 13 & Pesticide cost & & $556.99(0.55)$ & & $463.13(0.49)$ & & $516.23(0.56)$ \\
\hline 14 & Pesticides application cost & & $355.68(0.35)$ & & $297.64(0.32)$ & & $322.22(0.36)$ \\
\hline 15 & Harvesting & & $3118.38(3.09)$ & & $3087.50(3.28)$ & & $3112.20(3.39)$ \\
\hline 16 & Wheat straw making & & $5088.20(5.04)$ & & $5156.13(5.47)$ & & $5248.75(5.72)$ \\
\hline 17 & Miscellaneous & & $762(0.75)$ & & $992.94(1.05)$ & & $808.93(0.88)$ \\
\hline 18 & Total (1 to 16$)$ & & $34252.68(33.93)$ & & $29320.63(31.13)$ & & $26697.98(29.12)$ \\
\hline 19 & $\begin{array}{l}\text { Interest on working } \\
\text { capital @ } 7 \text { per cent }\end{array}$ & & $2397.68(2.38)$ & & $2042.07(2.17)$ & & $1868.85(2.04)$ \\
\hline \multicolumn{3}{|c|}{ Variable cost (A) } & $36650.36(36.31)$ & & $31362.70(33.15)$ & & $28566.83(31.15)$ \\
\hline 20 & Transportation & & $1389.68(1.38)$ & & $1407.90(1.49)$ & & $1395.55(1.52)$ \\
\hline 21 & $\begin{array}{l}\text { Management charges@10 } \\
\text { per cent }\end{array}$ & & $3665.04(3.63)$ & & $3136.27(3.31)$ & & $2856.68(3.12)$ \\
\hline 22 & Risk factor@10 per cent & & $3665.04(3.63)$ & & $3136.27(3.31)$ & & $2856.68(3.12)$ \\
\hline 23 & Rental value of land & & $55575(55.05)$ & & $55328(58.74)$ & & $56007.25(61.09)$ \\
\hline 24 & Total Fixed cost (B) & & $64294.76(63.69)$ & & $63008.04(66.85)$ & & $63116.16(68.85)$ \\
\hline 25 & Total cost $(\mathrm{A}+\mathrm{B})$ & & $100945.12(100)$ & & $94370.74(100)$ & & $91682.99(100)$ \\
\hline
\end{tabular}

Figure in the parenthesis represents per cent, CT = Conventional Technique, ZTT = Zero tillage Technique, THST = Turbo Happy Seeder, $₹=$ Rupees.

Table 2: Returns from wheat cultivation in Karnal district of Haryana (₹/ha.)

\begin{tabular}{|c|c|c|c|c|c|c|c|}
\hline \multirow{2}{*}{ S1. No. } & \multirow{2}{*}{ Particulars } & \multicolumn{2}{|r|}{ CT } & \multicolumn{2}{|c|}{ ZTT } & \multicolumn{2}{|c|}{ THST } \\
\hline & & No./Qty. & Value (₹) & No./Qty. & Value (₹) & No./Qty. & Value (₹) \\
\hline \multirow[t]{3}{*}{1} & Production (qtl.) & & & & & & \\
\hline & Main & 54.96 & 95351.26 & 54.04 & 93744.22 & 56.32 & 97708.26 \\
\hline & By Product & & 12164.75 & & 11275.55 & & 12658.75 \\
\hline 2 & Gross Returns & & 107516.01 & & 105019.77 & & 110367 \\
\hline 3 & Returns over variable cost & & 70865.65 & & 73657.07 & & 81800.17 \\
\hline 4 & Net returns & & 6570.89 & & 10649.03 & & 18684.01 \\
\hline 5 & B:C Ratio & & 1.07 & & 1.12 & & 1.20 \\
\hline
\end{tabular}

CT = Conventional Technique, ZTT = Zero tillage Technique, THST = Turbo Happy Seeder,$₹=$ Rupees. 
Table 3: Cost of wheat cultivation in Kaithal district of Haryana (₹/ha.)

\begin{tabular}{|c|c|c|c|c|c|c|c|}
\hline \multirow{2}{*}{ S1. No. } & \multirow{2}{*}{ Inputs } & \multicolumn{2}{|r|}{ CT } & \multicolumn{2}{|r|}{ ZTT } & \multicolumn{2}{|r|}{ THST } \\
\hline & & No./Qty & Value (₹) & No./Qty & Value (₹) & No./Qty & Value (₹) \\
\hline 1 & Preparatory Tillage & 4.45 & $5495.75(5.49)$ & & & & \\
\hline 2 & Pre-sowing Irrigation & & $781.76(0.78)$ & & $755.82(0.81)$ & & \\
\hline 3 & Seed $(\mathrm{kg})$ & 119.18 & $2741.08(2.74)$ & 104.73 & $2408.74(2.58)$ & 107.07 & $2462.711(2.68)$ \\
\hline 4 & Seed Treatment & & $149.44(0.15)$ & & $158.08(0.17)$ & & $156.85(0.17)$ \\
\hline 5 & Sowing & & $1062.10(1.06)$ & & $1869.79(2)$ & & $3087.50(3.37)$ \\
\hline \multirow[t]{5}{*}{8} & Fertilizer Nutrients & & & & & & \\
\hline & Urea (Kg) & 280.96 & $1657.69(1.66)$ & 287.14 & $1694.12(1.81)$ & 293.31 & $1730.56(1.89)$ \\
\hline & DAP (Kg) & 133.63 & $3207.05(3.20)$ & 135.85 & $1360.40(3.49)$ & 139.56 & $3349.32(3.65)$ \\
\hline & Potash $(\mathrm{Kg})$ & 9.88 & $118.56(0.12)$ & & & & \\
\hline & Zinc Sulphate (Kg) & 9.88 & $296.40(0.30)$ & 9.88 & $296.40(0.32)$ & 11.12 & $333.45(0.36)$ \\
\hline \multirow[t]{2}{*}{11} & Hoeing/ Weeding & & & & & & \\
\hline & Chemical & & $1432.60(1.43)$ & & $1404.20(1.50)$ & & $1336.27(1.46)$ \\
\hline 12 & Weedicides application cost & & $841.04(0.84)$ & & $815.10(0.87)$ & & $765.70(0.83)$ \\
\hline 13 & Pesticide cost & & $518.70(0.52)$ & & $419.90(0.45)$ & & $523.64(0.57)$ \\
\hline 14 & Pesticides application cost & & $334.83(0.33)$ & & $284.05(0.30)$ & & $338.39(0.37)$ \\
\hline 15 & Harvesting & & $3087.50(3.08)$ & & $3068.98(3.28)$ & & $3130.73(3.41)$ \\
\hline 16 & Wheat straw making & & $5057.33(5.05)$ & & $5125.25(5.49)$ & & $5211.70(5.68)$ \\
\hline 17 & Miscellaneous & & $770.64(0.77)$ & & 1009 (1.08) & & $794.11(0.87)$ \\
\hline 18 & Total (1 to 17$)$ & & $333802.99(33.75)$ & & $28765.15(30.79)$ & & $26739.43(29.15)$ \\
\hline 19 & $\begin{array}{l}\text { Interest on working capital } \\
@ 7 \text { per cent }\end{array}$ & & $2366.21(2.36)$ & & $2013.57(2.16)$ & & $1871.77(2.04)$ \\
\hline 24 & Total Fixed cost $(\mathrm{B})$ & & $64009.09(63.89)$ & & $62656.74(67.05)$ & & $63122.04(68.81)$ \\
\hline 25 & Total cost $(A+B)$ & & $100178.29(100)$ & & $93435.46(100)$ & & $91733.24(100)$ \\
\hline
\end{tabular}

Figure in the parenthesis represents per cent, CT = Conventional Technique, ZTT = Zero tillage Technique, THST = Turbo Happy Seeder, $₹=$ Rupees.

to conventional technique (CT) ( $₹$ 107516.01) (₹ 6570.89/ha) and zero tillage technique (ZTT) (₹ 105019.77) (₹ 10649.03/ha) respectively. As far as benefit cost ratio is concerned, turbo happy seeder was observed profitable (1.20) over zero tillage (1.12) and conventional technique (1.07) in the study area. These results are in confirmatory with Grover et al. (2011) and Raju et al. (2012) in their study.

Cost of wheat cultivation under conventional technique (CT), zero tillage technique (ZTT) and turbo happy seeder technique (THST) in wheat in Kaithal district of Haryana is presented in Table 3. Per hectare total cost of cultivation in conventional technique of wheat (₹ 100178.29/ha) was estimated to be higher as compared to zero tillage and turbo happy seeder technique ( $₹$ 93435.46) ( $₹$ 91733.24) respectively. The share of variable cost and fixed cost in total cost of conventional technique of wheat were 36.11 per cent ( $₹ 36169.20 /$ ha) and 63.89 per cent (₹ 64009.09) respectively. In case of zero tillage technique of wheat the share of variable cost and fixed cost were found to be 32.95 per cent (₹ 30778.72/ha) and 67.05 per cent (₹ 62656.74/ ha) respectively. Similarly in case of turbo happy seeder technique of wheat the share of variable cost and fixed cost were found to be 31.19 per cent 
Table 4: Returns from wheat cultivation in Kaithal district of Haryana during (₹/ha.)

\begin{tabular}{|c|c|c|c|c|c|c|c|}
\hline \multirow{2}{*}{ S1. No. } & \multirow{2}{*}{ Particulars } & \multicolumn{2}{|r|}{ CT } & \multicolumn{2}{|r|}{ ZTT } & \multicolumn{2}{|r|}{ THST } \\
\hline & & No./Qty. & Value (₹) & No./Qty. & Value (₹) & No./Qty. & Value (₹) \\
\hline \multirow[t]{3}{*}{1} & Production (qtl.) & & & & & & \\
\hline & Main & 54.46 & 94494.17 & 53.30 & 92458.58 & 55.45 & 96208.35 \\
\hline & By Product & & 11423.75 & & 11238.50 & & 12535.25 \\
\hline 2 & Gross Returns & & 105917.92 & & 103697.08 & & 108743.60 \\
\hline 3 & Returns over variable cost & & 69748.72 & & 72918.36 & & 80132.40 \\
\hline 4 & Net returns & & 5739.63 & & 10261.62 & & 17010.36 \\
\hline 5 & B:C Ratio & & 1.06 & & 1.11 & & 1.19 \\
\hline
\end{tabular}

$C T=$ Conventional Technique, ZTT $=$ Zero Tillage Technique, THST $=$ Turbo Happy Seeder,$₹=$ Rupees.

Table 5: Overall cost of wheat cultivation in Haryana (₹/ha)

\begin{tabular}{|c|c|c|c|c|c|c|c|}
\hline \multirow{2}{*}{ S1. No. } & \multirow{2}{*}{ Inputs } & \multicolumn{2}{|r|}{$\mathrm{CT}$} & \multicolumn{2}{|r|}{ ZTT } & \multicolumn{2}{|r|}{ THST } \\
\hline & & No./Qty & Value (₹) & No./Qty & Value (₹) & No./Qty & Value (₹) \\
\hline 1 & Preparatory Tillage & 4.33 & $5341.38(5.31)$ & & & & \\
\hline 2 & Pre-sowing Irrigation & & $783.61(0.78)$ & & $759.53(0.81)$ & & \\
\hline 3 & Seed $(\mathrm{kg})$ & 120.10 & $2762.39(2.75)$ & 106.21 & $2442.83(2.60)$ & 105.84 & $2434.31(2.65)$ \\
\hline 4 & Seed Treatment & & $148.20(0.15)$ & & $160.55(0.17)$ & & $160.55(0.18)$ \\
\hline 5 & Sowing & & $1067.04(1.06)$ & & $1876.58(2.03)$ & & $3099.85(3.38)$ \\
\hline 6 & Ridging & & $246.38(0.25)$ & & & & \\
\hline 7 & FYM (qtls) & 68.97 & $2069.43(2.06)$ & 66.53 & $1703.23(2.00)$ & & \\
\hline \multirow[t]{6}{*}{8} & Fertilizer Nutrients & & & & & & \\
\hline & Urea (Kg) & 284.05 & $1675.91(1.67)$ & 288.68 & $1703.23(1.82)$ & 291.77 & $1721.44(1.88)$ \\
\hline & $\mathrm{DAP}(\mathrm{Kg})$ & 134.62 & $3230.76(3.21)$ & 135.97 & $3263.36(3.48)$ & 137.58 & $3301.90(3.60)$ \\
\hline & Potash $(\mathrm{Kg})$ & 12.35 & $148.20(0.15)$ & & & & \\
\hline & Zinc Sulphate (Kg) & 7.72 & $231.56(0.23)$ & 9.26 & $277.88(0.30)$ & 12.35 & $370.50(0.40)$ \\
\hline & Total Fertilizer Investment & & $5286.43(5.26)$ & & $5244.46(5.59)$ & & $5393.84(5.88)$ \\
\hline 9 & Fertilizer Application cost & & $524.260 .52)$ & & $504.50(0.54)$ & & $566.25(0.62)$ \\
\hline 10 & Irrigation & 4.70 & $3679.68(3.66)$ & 5 & $3797.63(4.05)$ & 4 & $2926.95(3.19)$ \\
\hline \multirow[t]{2}{*}{11} & Hoeing/ Weeding & & & & & & \\
\hline & Chemical & & $1457.92(1.45)$ & & $1412.22(1.51)$ & & $1348(1.47)$ \\
\hline 12 & Weedicides application cost & & $852.77(0.85)$ & & $821.88(0.88)$ & & $779.29(0.85)$ \\
\hline 13 & Pesticide cost & & $537.84(0.53)$ & & $441.51(0.47)$ & & $519.94(0.57)$ \\
\hline 14 & Pesticides application cost & & $345.26(0.34)$ & & $290.84(0.31)$ & & $335.30(0.37)$ \\
\hline 15 & Harvesting & & $3102.94(3.09)$ & & $3078.24(3.28)$ & & $3121.46(3.40)$ \\
\hline 16 & Wheat straw making & & $5072.76(5.05)$ & & $5140.69(5.48)$ & & $5230.23(5.70)$ \\
\hline 17 & Miscellaneous & & $766.32(0.76)$ & & $1000.97(1.07)$ & & $801.52(0.87)$ \\
\hline 18 & Total (1 to 16$)$ & & $34027.84(33.84)$ & & $29042.89(30.96)$ & & $26718.71(29.13)$ \\
\hline 19 & $\begin{array}{l}\text { Interest on working capital @7 } \\
\text { per cent }\end{array}$ & & $2381.94(2.37)$ & & $2027.82(2.16)$ & & $1870.31(2.04)$ \\
\hline \multicolumn{2}{|c|}{ Variable cost $(\mathrm{A})$} & & $36409.78(36.21)$ & & $31070.71(33.04)$ & & $28589.02(31.17)$ \\
\hline 20 & Transportation & & $1387.59(1.37)$ & & $1414.07(1.51)$ & & $1363.17(1.49)$ \\
\hline 21 & $\begin{array}{l}\text { Management charges @10 per } \\
\text { cent }\end{array}$ & & $3640.98(3.62)$ & & $3107.07(3.30)$ & & $2858.90(3.12)$ \\
\hline 22. & Risk factor @ 10 per cent & & $3640.98(3.62)$ & & $3107.07(3.30)$ & & $2858.90(3.12)$ \\
\hline 23. & Rental value of land & & $55482.37(55.18)$ & & $55204.50(58.84)$ & & $56038.12(61.10)$ \\
\hline 24. & Total Fixed cost (B) & & $64151.92(63.79)$ & & $62832.71(66.96)$ & & $63119.09(68.83)$ \\
\hline 25. & Total cost $(\mathrm{A}+\mathrm{B})$ & & $100561.70(100)$ & & $93903.42(100)$ & & $91708.11(100)$ \\
\hline
\end{tabular}

Figure in the parenthesis represents per cent, CT = Conventional Technique, ZTT = Zero tillage Technique, THST = Turbo Happy Seeder, $₹=$ Rupees. 
Table 6: Overall returns from wheat cultivation in Haryana (₹/ha.)

\begin{tabular}{|c|c|c|c|c|c|c|c|}
\hline \multirow{2}{*}{$\begin{array}{l}\text { S1. } \\
\text { No. }\end{array}$} & \multirow{2}{*}{ Particulars } & \multicolumn{2}{|r|}{ CT } & \multicolumn{2}{|c|}{ ZTT } & \multicolumn{2}{|c|}{ THST } \\
\hline & & No./Qty. & Value (₹) & No./Qty. & Value (₹) & No./Qty. & Value (₹) \\
\hline \multirow[t]{3}{*}{1} & Production (qtl.) & & & & & & \\
\hline & Main & 54.71 & 94922.72 & 53.67 & 93101.40 & 55.88 & 96958.31 \\
\hline & By Product & & 11794.25 & & 11257.03 & & 12597 \\
\hline 2 & Gross Returns & & 106716.97 & & 104358.43 & & 109555.31 \\
\hline 3 & Returns over variable cost & & 70307.19 & & 73287.72 & & 80966.29 \\
\hline 4 & Net returns & & 6155.27 & & 10455.01 & & 17847.20 \\
\hline 5 & B:C Ratio & & 1.06 & & 1.11 & & 1.19 \\
\hline
\end{tabular}

CT = Conventional Technique, ZTT = Zero tillage Technique, THST $=$ Turbo Happy Seeder,$₹=$ Rupees.

(₹ 28611.20/ha) and 68.8 per cent ( $₹ 63122.04 /$ ha) respectively. Similar trend were observed by Raju, R., Thimmappa, K. and Tripathi, R.S. (2012) in their study Economics of zero tillage and conventional methods of rice and wheat production in Haryana.

Profitability from wheat cultivation in Kaithal district of Haryana is presented in Table 4. Per hectare gross returns were estimated to be higher (₹ 108743.60) in turbo happy seeder technique (THST) compared to conventional technique (CT) (₹ 105917.92) and zero tillage technique (ZTT) (₹ 103697.08), Whereas, higher net returns were found to be in case of turbo happy seeder technique i.e. ₹ 17010.36 per hectare in comparison to zero tillage technique ( $₹$ 10261.62/ha) and conventional technique ( $₹ 5739.63 /$ ha) due to lower cost of wheat cultivation in zero tillage and turbo happy seeder as compared to conventional technique. As far as benefit cost ratio is concerned, turbo happy seeder was observed to be comparatively more profitable with $\mathrm{B}: \mathrm{C}$ ratio of 1.19 over (ZTT) and (CT) with $\mathrm{B}: \mathrm{C}$ ratio of 1.11 and 1.06 respectively.

Overall basis, the cost of cultivation of wheat under conventional technique (CT), zero tillage technique (ZTT) and turbo happy seeder technique (THST) in Haryana is presented in Table 5. The results revealed that per hectare total cost of cultivation in conventional technique of wheat ( $₹$ 100561.70) was estimated to be higher as compared to zero tillage and turbo happy seeder technique i.e. ₹ 93903.42 and ₹ 91708.11 respectively. The share of variable cost and fixed cost in total cost of conventional technique of wheat were observed 36.21 per cent (₹ 36409.78/ha) and 63.79 per cent (₹ 64151.92/ ha) respectively. In case of zerotillage technique of wheat the share of variable cost and fixed cost were found to be 33.04 per cent ( $₹ 31070.71 /$ ha) and
66.96 per cent ( $₹ 62832.71 /$ ha). Similarly in case of turbo happy seeder technique of wheat the share of variable cost and fixed cost were found to be 31.17 per cent ( $₹ 28589.02 / \mathrm{ha}$ ) and 68.83 per cent (₹ 63119.09/ha) in the study area. These results are in agreement with the findings of Gupta et al. (2012) and Akhter et al. (2016) in their study.

Overall profitability from wheat cultivation in Haryana is presented in Table 6. Per hectare gross returns were estimated to be higher ( $₹$ 109555.31) in case of turbo happy seeder technique (THST) as compare to conventional technique (CT) i.e. ₹ 106716.97 and zero tillage technique (ZTT) i.e. ₹ 104358.43, Whereas, net returns were found to be higher in case of turbo happy seeder technique i.e. ₹ 17847.20 per hectare in comparison to zero tillage technique ( $₹$ 10455.01/ha) and conventional technique (₹ 6155.27/ha) due to lower cost of wheat cultivation in zero tillage and turbo happy seeder as compared to conventional technique. As far as benefit cost ratio is concerned, turbo happy seeder was observed to be comparatively more profitable (1.19) over zero tillage i.e. (1.11) and conventional technique i.e.(1.06) in the study area. Similar trend were observed by Yogi et al. (2015) in their study.

\section{CONCLUSION}

Costs and returns associated with wheat cultivation under different techniques of cultivation were compared. It was concluded that cost of cultivation of conventional technique (CT) was higher than zero tillage technique (ZTT) and turbo happy seeder technique (THST) in Karnal district. This was applied for Kaithal district as well. Major components among the highest variable cost for conventional technique (CT) in Karnal district were total fertilizer investment, preparatory tillage, wheat 
straw making and irrigation cost, it was the same for Kaithal also district. Similarly in case of zero tillage technique (ZTT) highest variable cost were total fertilizer investment, wheat straw making, irrigation and harvesting for both the districts. While in turbo happy seeder technique (THST), highest variable costs were total fertilizer investment, wheat straw making and sowing for the both district.

Returns from conventional technique $(\mathrm{CT})$, zero tillage technique (ZTT) and turbo happy seeder technique (THST) were high in Karnal and slightly low in Kaithal. The total production of turbo happy seeder technique (THST) per hectare was higher than conventional technique (CT) and zero tillage technique (ZTT) on other hand the net return as well as B: C ratios of THST were higher than (ZTT) and $(\mathrm{CT})$.

\section{ACKNOWLEDGEMENTS}

Authors wish to acknowledge Chaudhary Charan Singh Haryana Agricultural University and all the farmers who participated in the study and made the study successful.

\section{REFERENCES}

Akhter, S., Kotro, R., Dar, N.A., Rasool, R. and Uddin, R.M. 2016. Resource conservation technology in rice wheat cropping system. J. Recent Trends in Nat. Sci., 1(2): 23-46.

Grover, D.K. and Sharma, T. 2011. Alternative resources conservative technology in agriculture: Impact analysis of zero tillage technology in Punjab. Ind. J. Agril. Res., 45(4): 283-290.

Gupta, R. 2012. The Happy Seeder: An agricultural solution to air pollution in South Asia. Int. J. Agril. Environ. Biotech., 10(3): 65-79.

Raju, R., Thimmappa, K. and Tripathi, R.S. 2012. Economics of zero tillage and conventional methods of rice and wheat production in Haryana. J. Soil Salinity and Water Qual., 22(1): 34-38.

Singh, M.P. and Kumar, V. 2005. Ripples of changes through zero-tillage technology for enhancement of productivity and conservation of resources: experiences of K.V.K. Bahraich. Conserve. Agri. Status Prospects, 11(5): 10-16.

Singh, R.P. Dhaliwal, H.S., Humphreys, E., Sidhu, H.S. and Blackwell, J. 2008. Economic assessment of the Happy Seeder for rice-wheat systems in Punjab, India. Ind. J. Agril. Res., 11(4): 1-30.

Yogi, V., Kar, A., Bhardwaj, S. and Mehla, V. 2015. Impact of zero tillage practices on economics of wheat cultivation in Haryana. Int. Res. J. Agril. Econ. Stat., 6(2): 376-381. 
